\title{
Productive pedagogies in expressive arts lessons in Malawi
}

\author{
Devika Naidoo and Grames Chirwa
}

\begin{abstract}
The national government in Malawi implemented a new Curriculum: the Primary Curriculum and Assessment Reform in 2007. The purpose of this study was to investigate the enactment of one of the Learning areas, Expressive Arts in three urban and three rural schools in Zomba district where teachers were first trained to teach Expressive Arts. The study is framed by the Productive Pedagogies framework (Lingard, Hayes, Ladwig, Mills, Bahr et al., 2001). Following a qualitative research design, data were collected through observation and post-observation interviews. Data analysis showed limited productive pedagogies in most lessons. The majority of lessons were predominantly characterised by lower intellectual quality, a focus on instrumental knowledge, integration at a superficial level, dominance of communalising and gendered practices rather than 'engagement with difference', prevalence of localising discourses 'rather than connectedness to the world' and a pedagogy aimed at national examinations. It appears that dominant pedagogic practices in the Expressive Arts classroom serve to position learners in parochial orientations and issues. There was an obvious disjuncture between the intended curriculum and enacted curriculum.
\end{abstract}

The overall findings is that the enacted curriculum gave students limited opportunities for the acquisition of knowledge and development of skills, values and attitudes required for them to actively participate in the changing Malawian context and to be able to compete successfully in other contexts.

\section{Introduction}

To improve the quality of education in Malawi, the national government embarked on curriculum reform in 2001. The Primary Curriculum and Assessment Reform (PCAR) implemented in 2007 intended to improve the quality of education in the country by addressing the weaknesses of the previous curriculum. The previous curriculum was seen as overloaded with content due to a wide range of subjects and teaching and learning was examination rather than learner oriented (Khomani, 2003). The PCAR is outcomes based and advocates integration of subject knowledge within 
themes in 9 Learning Areas, a facilitative pedagogy and continuous assessment.

Expressive Arts is one of the nine learning areas in the 2007 national curriculum. It is an integrated curriculum using themes such as body movements, conveying cultural messages, multi-cultural performances and dances to integrate across multiple subject disciplines including Creative Arts, Physical Education, Music, Drama and Needlecraft. Expressive Arts differs from its predecessors in that they were designed around objectives rather than outcomes, emphasised content rather than skills, advocated didactic rather than facilitative pedagogies and assessed students through formal summative examinations rather than continuous assessment. Through PCAR, the government aimed to shift education from content-based to outcomes-based education.

Following the introduction of the new national curriculum in Malawi in 2007, the purpose of this research was to explore the extent to which the Expressive Arts curriculum is being implemented as intended. The key research question posed in the study was: 'how do Expressive Arts teachers teach Expressive Arts two years into the implementation of the curriculum in Malawi?'

Although literature on Malawi indicates that teachers in the primary school sector face enormous constraints, Mhango (2010) observed that there are not many studies that investigated, in a crucial way, how such constraints impact on teachers' classroom practices in implementing a curriculum innovation. In this connection, Croft (2002), who studied the use of songs in English lessons of lower classes in primary schools in Malawi, argued that most of donor-funded research in the country focussed on factors affecting the quality of education rather than classroom practices. She therefore recommended a more critical investigation of how teachers implement the school curricula. Owing to the limited number of studies in this area, this study aimed at learning how teachers enacted the new Expressive Arts curriculum to meet the state's goal of improving the quality of education in Malawi.

\section{Productive pedagogies}

The notion of Productive Pedagogies emerged from the School Reform Longitudinal Study (SRLS) which was conducted in Queensland Schools, 
Australia between 1998 to 2001 (Zohir and Razak, 2010). The theory was developed by Lingard, et al. (2001). The theory is not a neutral framework. It has an ideological basis. It aimed at advancing the education of children of under privileged background in Australia. It emerged as a research tool for exploring classroom practices that promote a high quality education for all students, regardless of background. Previous classroom studies indicate that classrooms high in intellectual quality help students to perform well academically (Boaler, 1997; Hayes, Ladwig, Lingard, Mills, Bahr et al., 2006; Oakes, Gamoran and Page, 1992).

Productive Pedagogies framework has four dimensions, namely; Intellectual quality of lessons; Engagement with difference; Connectedness to the world outside the classroom and Supportive classroom environment. According to the Productive Pedagogy framework, the dimension of intellectual quality stresses the importance of all students, regardless of background and perceived academic ability, being presented with intellectually challenging work. Challenging work is of particular importance for students from traditionally underachieving background, for example, students from low socio-economic backgrounds. According to Lingard, et al. (2001), there are many structural practices in schools, for example, streaming, which work against all students experiencing intellectually challenging work. Lingard, et al. further argues that it is mostly students in 'disadvantaged' schools who are most likely to be 'drilled or skilled' in ways that do not encourage high level thinking and critical engagement with knowledge. The intellectual quality dimension is indicated by six indicators: higher order thinking, deep knowledge, deep understanding, knowledge as problematic, substantive conversation and meta-language. The dimension of engagement with difference stresses on making lessons relevant for students by basing the lessons on their own cultures, as the background knowledge which they already have, if genuine understanding is to be achieved. According to Lingard, et al. (2001), basing the lessons on the students culture is particularly important if the curriculum is to accommodate the needs of low achieving students. The dimension of engagement with difference has five indicators: cultural knowledge, inclusivity, narrative, group identity and active citizenship. In the Productive Pedagogies framework, Connectedness to the world beyond the classroom also stresses on making lessons relevant for students by basing the lessons on what the students already know if genuine understanding is to be achieved. The connectedness to the world beyond the classroom dimension is indicated by four indicators: connectedness to the world, background knowledge, knowledge integration and problem-based 
curriculum. The dimension of Supportive classroom environment suggests that students be given a voice in the classroom in order to have some say over the direction that activities take within lessons. Lingard, et al. (2001), argues that while care of students is central to good teachers' work, care must become more than charity or control, it must become a relationship in which those who are cared for (pupils and even parents) have agency, dignity and a voice. Lingard, et al.further argues that in developing positive and mutually supportive relationships, the importance of breaking down the power imbalances between teachers and students is particularly important, given many students' resistances to being overpowered and controlled (p.6). Lingard, et al also argues that in a supportive classroom environment, an explicit criteria should be provided to students so that expectations are clear, and that a classroom environment is created where students are prepared to take risks with their learning. According to Lingard, et al. (2001), explicit criteria however have to be both related to students' school work and to their performances of being a good citizen, as the notion of a good student should include one who is not just concerned about academic achievement but also being a positive member of a democratic community. The supportive classroom environment dimension has five indicators: student direction, student self-regulation, academic engagement, social support and explicit quality performance criteria.

The four dimensions of Productive Pedagogies and their indicators are summarised in Table 1 below: 
Table 1: Productive pedagogy dimensions, items and key questions addressed

\begin{tabular}{|c|c|c|}
\hline Dimension & Indicator & $\begin{array}{l}\text { Key questions asked to detect the presence of the } \\
\text { indicator }\end{array}$ \\
\hline \multirow[t]{6}{*}{$\begin{array}{l}\text { Intellectural } \\
\text { quality }\end{array}$} & $\begin{array}{l}\text { Higher order } \\
\text { thinking }\end{array}$ & $\begin{array}{l}\text { - Are students required to manipulate information and } \\
\text { ideas to arrive at new meanings? } \\
\text { - Is critical analysis occurring? } \\
\text { - Are students required to combine facts and ideas in } \\
\text { order to synthesise, generalise, explain, hypothesise or } \\
\text { arrive at some conclusion or interpretation? }\end{array}$ \\
\hline & $\begin{array}{l}\text { Deep } \\
\text { knowledge }\end{array}$ & $\begin{array}{l}\text { - Does the lesson cover central ideas and concepts in any } \\
\text { depth, detail or level of specificity? }\end{array}$ \\
\hline & $\begin{array}{l}\text { Deep } \\
\text { understanding }\end{array}$ & $\begin{array}{l}\text { Do the work and responses of the students demonstrate } \\
\text { a deep understanding of concepts or ideas? }\end{array}$ \\
\hline & $\begin{array}{l}\text { Substantive } \\
\text { conversation }\end{array}$ & $\begin{array}{l}\text { Does classroom talk lead to sustained conversational } \\
\text { dialogue between students, and between teacher and } \\
\text { students, to create or negotiate understanding of subject } \\
\text { matter? }\end{array}$ \\
\hline & $\begin{array}{l}\text { Knowledge } \\
\text { problematic }\end{array}$ & $\begin{array}{l}\text { - Are students critically examining texts, ideas and } \\
\text { knowledge? To what degree is knowledge presented as } \\
\text { constructed? }\end{array}$ \\
\hline & Meta-language & $\begin{array}{l}\text { - Are aspects of language, grammar and technical } \\
\text { vocabulary being given prominence? }\end{array}$ \\
\hline \multirow{4}{*}{$\begin{array}{l}\text { Connectedness } \\
\text { to the world } \\
\text { beyond the } \\
\text { classroom }\end{array}$} & $\begin{array}{l}\text { Connectedness } \\
\text { to the world }\end{array}$ & $\begin{array}{l}\text { - Is the lesson, activity or task connected to competencies } \\
\text { or concerns beyond the classroom or real-life contexts? }\end{array}$ \\
\hline & $\begin{array}{l}\text { Background } \\
\text { knowledge }\end{array}$ & $\begin{array}{l}\text { - Are links with students' background knowledge made } \\
\text { explicit? } \\
\text { - Are there attempts to explore students' prior } \\
\text { knowledge? }\end{array}$ \\
\hline & $\begin{array}{l}\text { Knowledge } \\
\text { integration }\end{array}$ & - Does the lesson integrate a range of subject areas? \\
\hline & $\begin{array}{l}\text { Problem-based } \\
\text { curriculum }\end{array}$ & $\begin{array}{l}\text { Is there focus on identifying and solving intellectual } \\
\text { and/or real world problems that have no specific correct } \\
\text { solution? }\end{array}$ \\
\hline
\end{tabular}




\begin{tabular}{|c|c|c|}
\hline \multirow[t]{5}{*}{$\begin{array}{l}\text { Engagement } \\
\text { with difference }\end{array}$} & $\begin{array}{l}\text { Cultural } \\
\text { knowledge }\end{array}$ & $\begin{array}{l}\text { Are there explicit attempts to bring in beliefs, } \\
\text { languages, practices and ways of knowing } \\
\text { non-dominant cultures (e.g. in terms of gender, } \\
\text { ethnicity, race, religion, economic status, sexuality or } \\
\text { youth)? }\end{array}$ \\
\hline & Inclusivity & $\begin{array}{l}\text { - Are there deliberate attempts to increase the } \\
\text { participation of students of different backgrounds? }\end{array}$ \\
\hline & Narrative & $\begin{array}{l}\text { - Is the style of teaching principally narrative, or is it } \\
\text { expository? }\end{array}$ \\
\hline & Group identity & $\begin{array}{l}\text { Does the teaching build a sense of community and } \\
\text { identity for different groups within the classroom? }\end{array}$ \\
\hline & Citizenship & - Are there attempts made to foster active citizenship? \\
\hline \multirow[t]{5}{*}{$\begin{array}{l}\text { Supportive } \\
\text { classroom } \\
\text { environment }\end{array}$} & Engagement & $\begin{array}{l}\text { Are students engaged and on task?; are they attentive, } \\
\text { doing the assigned work, contributing to group tasks } \\
\text { and helping peers?; Or are they sleeping, day-dreaming, } \\
\text { making a noise or otherwise disrupting the class? }\end{array}$ \\
\hline & $\begin{array}{l}\text { Student self } \\
\text { regulation }\end{array}$ & $\begin{array}{l}\text { - Are students regulating their own behaviour, or is the } \\
\text { teacher involved in giving directions on student } \\
\text { behaviour? }\end{array}$ \\
\hline & $\begin{array}{l}\text { Student } \\
\text { direction of } \\
\text { activities }\end{array}$ & $\begin{array}{l}\text { - Do students have any say in the pace, direction or } \\
\text { outcomes of the lesson? }\end{array}$ \\
\hline & Social support & $\begin{array}{l}\text { - Is the classroom a socially supportive and positive } \\
\text { environment? } \\
\text { Does the teacher convey high expectations for all } \\
\text { students, including the expectation that they take } \\
\text { intellectual risks and try to master challenging academic } \\
\text { work? } \\
\text { - Is there a climate of mutual respect? }\end{array}$ \\
\hline & $\begin{array}{l}\text { Explicit quality } \\
\text { performance } \\
\text { criteria }\end{array}$ & $\begin{array}{l}\text { - Are the criteria for judging the range of student } \\
\text { performance made explicit? }\end{array}$ \\
\hline
\end{tabular}

Hugo, Bertram, Green and Naidoo (2008) basing his arguments on Bernstein's theory of Knowledge and Control in British schools contends that although there are serious differences in the quality of schooling across different social classes within Britain, most schools are functioning entities 
with adequate resources and staffing, unlike schools in South Africa. For Bernstein the difficulty was explaining how inequality was being reproduced when schools in Britain were mostly delivering the content of the curriculum. A major part of his answer was to point to the different ways teaching and learning were relayed - to the modalities of pedagogy. If the message was tolerably the same, then the source of inequality lay in the different forms of its transmission, and these differences could be tracked to similar formal divisions in social class (Hugo, et al., 2008). Just like Bernstein, McLaughlin (1964) emphasises the importance of both knowledge and pedagogy. According to McLaughlin, the form of the message and its content formats consciousness of learners.

For this reason, 'Forms of Knowledge in the curriculum' as postulated by Moore and Muller (2001) was used as the lens to explore the forms of content knowledge which teachers taught. In this dimension, the distinctions of intrinsic and instrumental knowledge provided sharper categories of knowledge taught. According to Moore and Muller, Instrumental curriculum has content knowledge that seems to aim at imparting to the learners knowledge and skills that are prerequisite for entering a particular profession, accumulating power or influence or creating things (including ideas) of utility or beauty. The knowledge in an instrumentalist curriculum becomes a tool through which the needs, aspirations, interests and objectives of the society are articulated and addressed as learning experiences for the development of the individuals through teaching/learning process. The knowledge is supportive of what is seen as the needs of both the society and the economy and learners have to be socialised to the culture of the society and the world of work and the schools is seen as a source of useable knowledge.

Instrumental knowledge is thus knowledge that is a means to an end, not an end in itself. Intrinsic form of knowledge on the other hand is knowledge that is an end in itself. It is traditional subject discipline based knowledge which is aimed at developing the mind of an individual rather than for answering to the needs of what is seen as the needs of the economy and for preparing individuals for the global and more competitive knowledge-based economy of the future.

\section{Data collection}

Data were collected during a five-month period through prolonged 
engagement in interviews with twelve case study teachers and also persistent observations in their classrooms. At least a minimum of five lessons were observed in Expressive Arts for each of the twelve teachers in Standards 7 and Standard 8 at each school. This paper however is based on classroom observations as the primary source of data.

Two techniques were used to record data. A digital recorder was used to audio tape teachers and learners voice and field notes were made to capture what was done in the classroom. The audio tapes of lessons, transcribed by the researcher, generated more than three hundred pages of transcripts. The 71 lesson transcripts were scrutinised for evidence of the indicators of productive pedagogies.

\section{Participants}

The data was collected in six schools over a period of five months, from January, 2010 to May, 2010. In all, twelve Expressive Arts teachers drawn from the six state schools in Zomba were studied. The teachers represented Standards 7 and 8 in a school. All the teachers in the study were qualified. Their teaching experiences ranged from 5 to 20 years. Their ages ranged from 34 to 52 years. Seven of the teachers in the study were females and five were males. All 7 teachers were trained in the normal training programme of the teaching of Expressive Arts. The school and teacher samples used in the study are summarised in tables 2 and 3 below:

Table 2: Summary of study schools

\begin{tabular}{|l|c|c|c|c|c|c|}
\hline School & A & B & C & D & E & F \\
\hline Type & Rural & Urban & Rural & Urban & Rural & Urban \\
\hline Roll & 1333 & 725 & 761 & 1156 & 604 & 2743 \\
\hline Teachers & 21 & 25 & 16 & 34 & 8 & 61 \\
\hline $\begin{array}{l}\text { Teacher-pupil } \\
\text { ratio }\end{array}$ & $1: 63$ & $1: 29$ & $1: 95$ & $1: 34$ & $1: 75$ & $1: 45$ \\
\hline $\begin{array}{l}\text { Number of } \\
\text { teachers } \\
\text { participants }\end{array}$ & 2 & 2 & 2 & 2 & 2 & 2 \\
\hline
\end{tabular}


Table 3: Teachers of expressive arts biographical data

\begin{tabular}{|c|c|c|c|c|c|c|c|c|}
\hline & Gender & Age & $\begin{array}{c}\text { Teaching } \\
\text { standard }\end{array}$ & $\begin{array}{c}\text { Academic } \\
\text { qualifi- } \\
\text { cation }\end{array}$ & $\begin{array}{c}\text { Education } \\
\text { qualifi- } \\
\text { cation }\end{array}$ & $\begin{array}{c}\text { Teaching } \\
\text { experience }\end{array}$ & $\begin{array}{c}\text { Experience } \\
\text { in } \\
\text { expressive } \\
\text { arts }\end{array}$ & School \\
\hline 1 & Female & 45 & 8 & MSCE & T2 & 20 years & 1 year & $\mathrm{F}$ \\
2 & Female & 40 & 7 & MSCE & T2 & 14 years & 1 year & $\mathrm{A}$ \\
3 & Female & 34 & 8 & MSCE & T2 & 13 years & 1 year & B \\
4 & Female & 35 & 7 & MSCE & T2 & 10 years & 2 years & $\mathrm{B}$ \\
5 & Female & 39 & 7 & JCE & T2 & 16 years & 1 year & $\mathrm{F}$ \\
6 & Female & 40 & 8 & MSCE & T2 & 17 years & 2 years & A \\
7 & Female & 37 & 7 & MSCE & T2 & 14 years & 2 years & D \\
8 & Male & 38 & 7 & MSCE & T2 & 16 years & 2 years & C \\
9 & Male & 52 & 7 & MSCE & T2 & 10 years & 2 years & E \\
10 & Male & 36 & 8 & MSCE & T2 & 14 years & 2 years & E \\
11 & Female & 40 & 8 & MSCE & T2 & 15 years & 2 years & D \\
12 & Male & 42 & 8 & MSCE & T2 & 20 years & 2 years & C \\
\hline
\end{tabular}

Data analysis

Data analysis involves the researcher understanding and interpreting the data collected in order to generate findings, make conclusions and recommendations on the phenomenon under investigation (Merriam, 2002). The unit of analysis for data was Productive Pedagogies practices of teachers as postulated by Lingard, et al. (2001). The categories from the framework were applied to the entire data. Each category contained all pieces from the entire data body that were relevant to that category. The goal when analysing the data was to establish the lessons in which productive pedagogies were evident; specific teachers whose lessons illustrated productive pedagogies and variations in pedagogies within lessons.

This meant continuously moving backwards and forwards among the transcripts data. This process is like that described by Glaser and Strauss (1967) as the development of 'ground theory', the production of analysis and explanation which is grounded in the data. 
A sample analysis of an Expressive Arts lesson using Productive pedagogies framework is provided at the end of this article as an appendix.

\section{Findings}

The intellectual quality of lessons

Although a few lessons contained elements of higher intellectual quality, the majority of lessons were characterised by lower intellectual quality. Didactic teaching was very much the order of the day and little opportunity, if any, was provided for reflection and discussion with the pupils.

\section{Higher order thinking}

Data analysis showed that higher order thinking was hardly evident in the majority of the lessons. There were minimal possibilities for higher order thinking by the learners, as most of the Expressive Arts teachers did not encourage the learners to think deeply. The learners responses were restricted to two or three words without elaboration.

Below, an excerpt of an Expressive Arts lesson in a rural school that illustrates lower order thinking is examined.

Teacher: In today's lesson, we are going to look at sounds used to convey messages. In your communities, if you hear different sounds, you should be able to know that a certain type of sound conveys a certain type of message. Can you now be in your usual groups and discuss sounds which are produced in your communities which can be used to convey messages.

(The learners made four groups with one group consisting of boys only. I listened to the discussion of this group. There was very little discussion going on in the group. The only discussion taking place amongst the learners in the group was that one learner said, 'Drum is produce dancing', and another learner said, 'whistle is producing wedding'. The teacher then called group leaders to write on the chalkboard what they had discussed in their groups). 
(Representatives of the groups wrote the following on the chalkboard)

Group 1: drum - dances, ambulance - to take patients.

Group 2: drum - dancing, whisle -'nyau'.

Group 3: drum is produce dancing.

Group 4: Cock is telling time.

The discourse in the above excerpt showed that learners are involved in lower-order thinking. The low-level questions which the teacher asked did not encourage the learners to think deeper in the teaching and learning process.

While higher-order thinking was weakly evident in most of the lessons, some of the lessons observed showed some possibilities for higher-order thinking. Of the lessons observed, 39 percent (28 lessons out of 71) showed possibilities for higher-order thinking. Below, an episode illustrating the opportunity for higher order thinking in the lessons is examined.

Teacher: Yesterday, we discussed about the roles of the leaders. We talked about the characteristics of a leader and their leadership styles. Can you list the leadership styles which we discussed?

Learner: Autocratic

Teacher: Do we have characteristics of autocratic leadership?

Learner: Only the leader's voice count. What the leader says is the only thing which can be done. Nobody can say or can give ideas. No other ideas are welcome. Only the leader says this and so the people do whatever their leader tells them to do. The people just follow what the leader is telling them to do.

The above excerpt illustrates greater possibility for higher-order thinking. Learners were responding to their teachers' questions. In the extract, the teacher asked open-ended questions which required learners to manipulate information and ideas to respond to the teacher's questions.

\section{Deep knowledge}

Generally, very simplistic, unstructured, community, local and everyday discourses were being discussed.

Below, an episode illustrating superficial depth of knowledge taught in the lessons is examined. 
Teacher: From yesterday, I have seen that most of you do not understand the meaning of mirroring and so I will continue looking at it again and again. What we have been saying is the definition of mirroring? Who can try, anyone?

Yes?

Learner (Reading from the text book):

Mirroring is an activity which someone can copy from somebody.

Teacher: Yes, that is what we have been saying is the meaning of mirroring. Mirroring is an art of copying an action, words or expressions. . .

In the above excerpt, the concept of 'mirroring' has been very poorly co-extended. For example, the teacher explains the meaning of the main idea or concept to be covered in the lesson by asking a learner to just read from the textbook. The teacher does define the term 'mirroring' as an act of copying an action, words or expressions but does not elaborate or shed more light on each forms of mirroring and other concepts which have been read by the learner from the textbook.

\section{Instrumental forms of knowledge}

Generally, 'Instrumental' forms of knowledge were evident in more than half the lessons observed. The excerpt below, from a lesson conducted by Teacher 3 at school 'B,' an urban school, illustrates 'Instrumental' forms of knowledge in the Expressive Arts lessons observed.

The lesson began at 7:30 a.m. There were 41 children present that day. As part of the introduction of the day's Expressive Arts lesson, the teacher formally greeted the learners and began the lesson as follows:

Teacher: Today we will discuss about songs, about singing. O.K., can you just sing one song that you sing at your homes or here at school that expresses happiness or enjoyment. Sing one song. I want you to sing using soprano, tenor and bass.

(The teacher led the learners in singing the song: We are walking in the light of God, Allelujah, we are walking in the light of God. We are walking in the light of God.) 
Teacher: We are walking in the light of God Allelujah!

Learners (singing together):

We are walking in the light of God. We are walking in the light of God.

Teacher: Have you enjoyed?

Learners (collectively):

Yes

Teacher: Thank you for enjoying. Sometimes we need to enjoy.

In the above excerpt, the teacher must be commended for producing 'enjoyment' in the classroom. She is teaching the skills of singing and walking to the beat of the song that reflects what is valued by the local culture. The singing skills are apparently being taught to enable the learners to participate effectively in the social lives of their communities or societies. Teachers were thus observed to be focussing their teaching on those sections of the Expressive Arts curriculum which were on 'ethnic culture' of their communities or societies.

\section{Deep understanding}

Generally, deep understanding was hardly evident in the majority of the lessons. Most of the learners demonstrated understanding involving the coverage of everyday knowledge which they could easily remember and were able to provide feedback to the teacher, but there was lack of progression to conceptual knowledge that required the learners to do much reasoning, explanations and arguments. The questioning by the teachers in the lessons did not facilitate deep understanding on the part of the learners.

An in-depth analysis of data revealed that $87 \%$ (62 out of 71) of the lessons showed superficial understanding on the part of learners. The 62 lessons showed that the learners did not understand what they were being taught. For example, learners either failed to answer teachers' questions or in cases where they were able to answer their teacher's questions, their responses were mostly one-word answers which were mainly recitation of fragmented pieces of information which did not show understanding of what the learners were learning

Below, an excerpt that illustrates learners' superficial understanding is examined. 
Teacher: Do you now understand roles of a village head?

Learners: $N o$

Teacher: Ntchito za amfumu a m'mudzi simukudzimvetsa? (translated as: Is it really true that you do not understand the roles of a village head?)

Learner: $\mathrm{Mm}$.

Teacher: Ntchito za a mfumu a m'mudzi simukudzimvetsa zowona? (translated as: Are you really serious that you do not understand roles of a village head?

Learner: $\mathrm{Mm}$.

Teacher: Kumudzi kwanu nkuti? (translated as: Where do you come from yourselves?)

Learner: Lilongwe

Teacher: Ku Lilongweko sikukhala a mfumu? Kuli mfumu Mazengera kumenekuja yotchuka. Ndiye mfumu suyidziwa, tiwamvere chisoni eti? (translated as: So there are no village heads in Lilongwe. Do you not know that there is village headman Mazengera there? You should feel ashamed yourself).

The above excerpt shows that the teachers' presentation of the lesson, including questioning did not facilitate deep understanding of the lesson on the part of the learners. For example, teachers' remarks such as, 'Is it really true that you do not understand the roles of a village head?, 'Are you really serious that you do not understand roles of a village head?, and 'You should feel ashamed of yourself', shows that learners seemed to have been unable to answer even those questions which the teacher considered as simple, to the extent that the teacher rebuked and shouted at the learners, thinking that the learners were just being rude to her.

Although much of the pedagogy in the lessons was unproductive in deep knowledge coverage, there were some elements of deep knowledge coverage in some of the lessons. Data analysis revealed that $30 \%$ (21 out of 71) of the lessons were characterised by Deep knowledge, Below, an extract illustrating deep knowledge in the lessons is examined.

Teacher: We have seen the leaders of different styles. The leaders who practice democracy and the leaders who are dictators. The different types of leaders have different successes and challenges. Challenges is the same as problems. The leaders meet successes and challenges. Those leaders in your villages for example meet 
some issues which they are able to resolve without many difficulties. Those are what we call successes. However those leaders again meet some issues brought by their villagers which are difficult for them to resolve. (Those issues are what we call challenges). So we want to look at those things.

[I sat with one group which was composed of four girls and one boy. The learners wrote down the following facts; when leaders face challenges, they should not give up but they should find solutions to their challenges. The leader should practice justice. The leader should encourage people to work in unity and should not take any sides].

The above excerpt shows that Deep knowledge is being covered in the lessons because there is greater analysis and classification of leadership styles. These analytical classifications are successes of leaders, problems or challenges of leaders and solutions to the challenges which leaders face. Learners' responses in their groups also showed that they were developing deeper knowledge of leadership styles. This is evidenced from the fact that they are able to expound on the central ideas and concepts they have been assigned to work on.

\section{Substantive conversation}

Generally, substantive conversation was hardly evident in the classroom in the majority of the Expressive Arts lessons observed. There was more teacher talk and there were very limited two-way interactions between learners and between the teachers and the learners. Learners answered in a word or two to the teacher's questions. In-depth analysis of data revealed that $80 \%$ of the lessons were characterised by lack of substantive conversation between the learners and between the teacher and the learners.

The excerpt below, illustrates lack of substantive conversation in the lesson.

Teacher: Can you mention some of the garments which can be used to convey cultural messages which we discussed yesterday?

Learner: White dress

Teacher: What else?

Learner: Black garments

Teacher: Can you go into your groups and open your Expressive Arts text books on page 10. Can you discuss the materials which were used to make the garments which are shown in the pictures on page 10. 
[I listened to the discussion of one of the groups. One learner said, "chishango are animal hide." Another learner responded, "nyau dance is carton." There were three boys in this group who were not participating in the discussions of the group. The three boys were rather involved in some kind of play which seemed not to have been related to the activity which they had been assigned to work on].

In the above excerpt, there was little substantive conversation taking place between the learners or between the teacher and the learners. For example, in the entire nine minutes of group discussion in the above excerpt, there were only two responses made by the learners to the task given them. During much of the time, the learners seemed to have been engaged in off-task activities.

While substantive conversation was generally hardly evident in the majority of the lessons, there were a few lessons in which there were more substantive conversations.

Data revealed that substantive conversation was evident in $20 \%$ (14 out of 71 ) of the lessons.

The excerpt below, illustrates 'substantive conversation' in the observed lessons:

Teacher: Now in your group, you can just identify one type of dance. For example, a group can have Beni dance. And another group can have another type of dance. Can you identify those dances? Just one, one dance per group.

[I sat at a group composed of four girls and one boy. The boy told his colleagues ' kandiyandiya' (translated as: It is Kandiyandiya dance). One girl told the group, 'likhuba' (translated as: It is likhuba dance). Another girl asked her colleagues, 'Is a Likhuba a dance? The boy in the group responded, 'ee, ndimayesa ndi dance?' (translated as: Yes, I really thought this is a dance). The girl asked further, 'koma amavina nthawi yanji?' (translated as: But at what time of the day is this dance performed?) The boy answered, ' $k a y a$ ' (translated as: well, I don't really know). The girl enquired further, 'ndiye iwe sukudziwa?' (translated as: So you don't know as well). Another girl remarked, 'Likhuba dance' (translated as: It is Likhuba dance). The rest of the members of the group agreed with her and they wrote in their note books, 'likhuba' dance]. 
In the above excerpt, there was substantive conversation taking place amongst the learners because the learners were asking each other questions which were open-ended and had possibilities of sustaining the conversation amongst them. Each learner in the group was participating actively and making a contribution to sustain the discussion in the group.

\section{Knowledge as problematic}

Generally, knowledge as problematic was hardly evident in the majority of the lessons. In the majority of the lessons, all knowledge was presented as 'given', in an uncritical manner where there was no argumentative discussion on information between learners and teachers; the learners accepted almost all information given by the teachers instantly.

The excerpt below illustrates lack of presentation of knowledge as problematic in the lessons.

Teacher: (Reads for the learners from the Teacher's Guide).

O.K. Different body movements can convey specific messages. For example, a person might wave a hand like this rather than saying hello or nod his or head in agreement with whatever somebody is saying. The body movements can be useful in expression and communication because they are a big way to convey thoughts and feelings without speaking. There are certain messages to be conveyed and expressed by body movements. These messages are very important in any cultural setting. This is because it enhances cooperation amongst members of the same community. Is this clear?

Learners (collectively):

Yes

The above excerpt shows that the teacher presented knowledge as 'given', in an uncritical manner. The teacher did not create an opportunity for any debate or argument on the information presented to the learners. The teacher conducted a monologue and read the content of the Teacher's Guide to the learners. The above excerpt again illustrates the general practice of most of the teachers in the study that the teachers simply transmitted information to learners and that learners received information passively from their teacher. 


\section{Metalanguage}

Teachers discourse showed little evidence of instruction of metalinguistic concerns. Teachers did not really take into account or give feedback to learners' usage of language. They proceeded with their lessons without alerting learners to their own or learners' use of language.

In the observed lessons, only one teacher corrected the learners' incorrect pronunciation of the word 'pottery', which they were wrongly pronouncing as 'poultry'.

\section{Summary of intellectual quality of lessons}

Findings on Intellectual Quality Dimension of Productive Pedagogies found in the 71 lessons are summarised in Table 3 below.

Table 3: Summary of episodes in the indicators of high intellectual quality dimension

\begin{tabular}{|l|c|c|c|c|}
\hline \multicolumn{1}{|c|}{ Dimension } & Indicator 1 & Indicator 2 & Indicator 3 & Indicator 4 \\
\hline $\begin{array}{l}\text { High intellectual } \\
\text { quality }\end{array}$ & $\begin{array}{c}\text { Higher-order } \\
\text { thinking }\end{array}$ & Deep knowledge & $\begin{array}{c}\text { Deep } \\
\text { understanding }\end{array}$ & $\begin{array}{c}\text { Substantive } \\
\text { conversation }\end{array}$ \\
\hline $\begin{array}{l}\text { Percentage of } \\
\text { lessons }\end{array}$ & $39 \%$ & $30 \%$ & $13 \%$ & $20 \%$ \\
\hline
\end{tabular}

Engagement with difference

Generally, engagement with difference was hardly evident in the Expressive Arts lessons observed. A detailed analysis of each indicator of engagement with difference dimension of Productive Pedagogies as observed in the lessons is presented below.

\section{Cultural knowledge}

From the observations, generally, cultural knowledge coverage was evident in the lessons. However, only the cultures of the dominant ethnic groups in Malawi were recognised and emphasised. There was generally no explicit 
recognition, valuing or clear appreciation of cultures of small ethnic groups in Malawi or the cultures of other people outside the immediate environment of Malawi.

The extract below illustrates that only the cultures of the dominant ethnic groups in Malawi were emphasised in the lessons observed.

Teacher: It is now time for Expressive Arts. We are going to learn about multicultural performances. Who can define the term multicultural? Who can define the term multicultural performances? Yes?

Learner: Multicultural performances are performances for difference culture.

Teacher: So can you give me some examples of popular ethnic groups found in Malawi?

Learner: Yao

Teacher: Yao, yes?

Learner: Lomwe

Teacher: O.K. Thank you very much. Some of the popular ethnic groups found in Malawi are Lomwe and Yao. These are some examples of popular ethnic groups found in what?

In the above excerpt, the teacher tells the learners to discuss folk dances from Lomwe tribe, one of the dominant tribes in Malawi. This shows that there was no explicit recognition or valuing of cultures of other small ethnic groups in Malawi in the lesson, other than the dominant cultures.

Although coverage of cultural knowledge of small ethnic groups in Malawi was weakly evident in the lessons, the cultural knowledge the teachers brought to the classroom had some positive influence on teachers' practices in the classrooms. Some teachers occasionally used cultural tools such as songs and dances to help students participate in class.

\section{Inclusivity}

Generally, lack of recognition of small ethnic groups and non-dominant group participation in the lessons observed suggested that there was no inclusivity in the classrooms. Only Teacher 2 once in a while during the teaching and learning process made some attempts to get learners of different sexes actively involved in the lessons. 
For example, the excerpt below illustrates some inclusivity in the Expressive Arts lessons observed. In the lesson, the teacher encouraged learners to form groups with equal representation of boys and girls.

Teacher: Yesterday, we learned about mirroring. We said that mirroring are activities which somebody can mirror from his friends. Can you tell me what we said mirroring is?

Learner: Mirroring is an activity in which somebody imitates a friend.

Teacher: Yes, mirroring is an activity which you copy from a friend.

12:02: $\quad$ Can you be in groups of ten. I do not want to see groups of boy

Teacher: only and girls only.

In the above excerpt, the teacher was making explicit attempts to include learners of different sexes in the lesson when she said that, 'I do not want to see groups of boys only and girls only'. The teacher thus encouraged learners to make groups which were inclusive of different sexes.

On the other hand, $83 \%$ (66 out of 71) of the lessons showed lack of attention to gender inclusivity. The excerpt below illustrates lack of 'inclusivity' in the observed lessons:

Teacher: I welcome you to this lesson this morning. Today the topic is posture and body movements. Open your books on page 12. What I want you to do is to study the illustrations in the learners' book, secondly identify postures and body movements that express cultural values, and lastly, describe each posture and body movement. I want you in your groups to do this.

[One group composed of boys only. In the group one boy said, 'This picture shows respect.' Another boy asked, 'Kodi' (translated as: can I be enlightened) to show respect 'Ndikuwonetsa ulemu, eti?' (translated as: what does to show respect mean?). A third boy asked, 'Nanga ichi, chikuwonetsa chiya?' (translated as: what about this, what does it mean? Number B, 'Chikuwonetsa chiya?' (translated as: what does this number B, mean?].

In the above excerpt, there was no attempt by the teacher to include learners of different sexes in the group activities. Boys and girls were working on their own. 


\section{Group identities in a learning community}

Generally, the majority of Expressive Arts lessons showed few explicit attempts by teachers to help learners from different backgrounds feel part of the learning community in the classroom. Only one of the lessons observed showed an explicit attempt to build a sense of a learning community for learners of different backgrounds in the classroom.

The excerpt below illustrates this.

Teacher: Of course we kneel down in order to show respect to the old people. Today's topic will be cultural dances. O.K. there are some people here who can dance Manganje. Can you please come forward and demonstrate how to dance Manganje. But I want other learners who have not danced Manganje before also to come forward and join in the dancing.

The teacher acknowledged those learners who come from a tribe which dances 'Manganje' to take a lead in the dancing of 'Manganje' and at the same time, he also encouraged other learners who are not from such a tribe to also participate in the activity. In this way, the teacher created a learning community in which learners with different backgrounds felt part of the activities of the lesson.

\section{Narrative}

The original model of the Productive Pedagogies framework states that 'some non-mainstream learners, particularly indigenous children (of Australia), may learn best through narrative method, because of strong oral traditions and narrative practices extant in their communities.' This argument is also true of Malawi. Most Malawian children may learn best through narrative method, because of strong oral traditions and narrative practices extant in the country.

Data showed that narrative as a teaching style was seldom used in the lessons. Of the lessons observed, only one lesson had an element of narrative pedagogy.

The excerpt below shows that the teacher used narrative teaching in the lesson. 
Teacher: Tsopano mvetserani nthano iyi [translated as: now listen to this story]. There was a king in Israel called Solomon. Two women from the same house came to the king each with a baby in her hands. One of the women was carrying a dead baby and the other woman was a carrying a living baby. The woman carrying the dead baby told the king that it was not hers but the living one and that the other woman said so too. Therefore, they were quarrelling over the living baby. So the king commanded that the living baby should be cut into two to be shared equally between the women. The woman whom the living baby was not hers agreed, but the other woman pleaded with the king with a motherly compassion not to kill the baby. Eventually, the king gave the living son to the compassionate woman. All who heard this respected the king.

In the above excerpt, the teacher used narrative teaching. This is so because the teacher included telling a story (a Biblical one in this case) to illustrate the moral lesson which she wanted to teach to the learners through the day's lesson on types of leadership.

\section{Active citizenship}

Generally, this topic was not taught by teachers. Just one teacher discussed citizenship rights, responsibilities and practices of good citizenship.

Teacher: Can you tell us the story behind this picture? What is the picture about? What is the person doing there? Yes?

Learner: Vandalising the bridge

Teacher: Do you think removing wood from the bridge is good?

Learners: Nooo!

Teacher: It is not good to vandalise bridges because we are the same people who use the bridge.

In the above excerpt, Teacher 3 made an attempt in her lesson to promote 'ideals' of good citizenship like patriotism, loyalty to the nation and respect for the rule of law.

\section{Summary of engagement with difference}

The percentage of lessons and number of episodes indicating presence of 
Engagement with difference dimension in the 71 lessons are presented in Table 5 below.

Table 5: Percentage of lessons and number of episodes indicating presence of Engagement with Difference dimension in the 71 lessons.

\begin{tabular}{|l|c|c|c|c|c|}
\hline Dimension & Indicator 1 & Indicator 2 & Indicator 3 & Indicator 4 & Indicator 5 \\
\hline $\begin{array}{l}\text { Engagement } \\
\text { with } \\
\text { difference }\end{array}$ & $\begin{array}{c}\text { Cultural } \\
\text { knowledge }\end{array}$ & $\begin{array}{c}\text { Narrative } \\
\text { teaching }\end{array}$ & $\begin{array}{c}\text { Expository } \\
\text { teaching }\end{array}$ & Inclusivity & $\begin{array}{c}\text { Group } \\
\text { identity in a } \\
\text { learning } \\
\text { community }\end{array}$ \\
\hline $\begin{array}{l}\text { Number of } \\
\text { episodes in } \\
\text { the 71 } \\
\text { lessons }\end{array}$ & 92 & 1 & 70 & 6 & 1 \\
\hline $\begin{array}{l}\text { Percentage of } \\
\text { lessons }\end{array}$ & $92 \%$ & $1 \%$ & $99 \%$ & $7 \%$ & $1 \%$ \\
\hline
\end{tabular}

\section{Connectedness to the world beyond the classroom}

Generally, the majority of the lessons observed showed little connectedness to the world beyond the classroom. Only 43\% (31 lessons out of 71) of the lessons showed connectedness to the world beyond the classroom. A detailed analysis of each indicator of Connectedness to the world beyond the classroom is presented below.

\section{Connectedness to the world}

Although a few lessons contained elements of connectedness to the outside world, the majority of lessons were observed to have no connection to the world outside the classroom. In addition to this, the few lessons which contained activities with connection to the outside world had those connections restricted to the immediate environment of the classrooms, such as the cultures of the community from which the learners came and some national crises affecting the learners in the country. There was thus dominance of localising pedagogic discourses in the majority of the lessons. 
The excerpt below illustrates some localising pedagogic discourses which characterised the majority of the lessons.

Teacher: Choose something which you can draw. May be a tree, may be a school, a house, people who are sick because of HIV/AIDS, the cutting down of trees or any other problems affecting you in the country. You can think of those things. Also things like a school girl or a school boy. You can draw anything which you can think about.

The above excerpt is one of the examples which characterised the majority of the lessons in terms of their connectedness to the world beyond the classroom. The excerpt shows that although there were some attempts by the teachers to connect their lessons beyond the classroom, these connections were restricted to the immediate environment of the classrooms such as some national crises affecting the learners in the country. This practice deprived the learners the opportunity to develop knowledge, skills, attitudes and values which would enable them to deal with the challenges of their everyday lives and to enable them actively participate in the changing Malawi context.

\section{Background knowledge}

Generally, most of the lessons made some reference to learners' background knowledge, either to learners' daily experiences or their community. Of the observed lessons, $82 \%$ (58 out of 71) made some reference to the learners' background knowledge.

The excerpt below illustrates connection of the lessons observed to the learners' background knowledge:

Teacher: Yesterday, we discussed about the garments which convey messages. I would like to ask you a few questions about what we discussed yesterday. In our societies, if a woman puts on black dress, what does it symbolise, or what does that tell you?

Learners: Funerals

Teacher: Right, when you see a woman putting on black dress, normally it symbolises that somebody or a family member has died. 
In the above excerpt, the teacher related the lesson to the learners' knowledge of their culture. For example, the teacher began the lesson by asking the learners about what they knew about the culture of dressing for different occasions such as funerals in their societies. The teacher thus built the lesson on the learners' background knowledge which they brought with them to the classroom.

However, some teachers made no reference to learners' background knowledge, either to learners' daily experiences or their community. For example, the excerpt below illustrates lack of connection of some of the lessons to the learners' background knowledge.

Teacher: Today, we are looking at contemporary music. We are specifically looking at some of the things that are found in music. We are especially now looking at tempo and dynamics. Are we together? Now, first of all let us look at the term tempo. What is it? What is tempo? O.K. We are saying tempo. These are marks indicated at the beginning of a song. So these marks ndizo zimamuwuza munthu uja kuti [translated as: these punctuation marks indicate that] the tempos can be fast or slow.

In the excerpt above, there is no connection of the lesson to the learners' background knowledge. This is so because the teacher began the lesson by talking about concepts of contemporary music without building the topic or the subject matter of the day's lesson on learners' background knowledge, such as the learners' cultural songs or music.

Knowledge integration

Generally, most of the content taught by the teachers was limited to one subject discipline. Of the lessons observed, only $18 \%$ (6 out of 71 ) attempted to integrate knowledge. The excerpt below shows one of the few examples of integration of knowledge.

Teacher: Then we identified one dance for which we sung the song, chule anafera kwa mkazi wake koma maliro anapita kwawo [translated as: the frog died at the in-laws village but it was decided that he be buried at his own village of origin]. Now, what is the importance of this song?

Learner: Unity and cooperation. 
Teacher: Yes, it teaches us about unity and cooperation.

Teacher: Now we shall be performing this dance known as Manganje. We shall be in three groups but each group will perform Manganje and sing a song of their choice during the performance. Now let us go outside and perform Manganje. We will use this tin as a drum because we don't have a drum. Can you please compose a song in your groups and sing and dance to those songs using gestures.

[Learners went outside and were in their three groups singing their songs of Manganje. One group one sung the song, tipewe AIDS chifukwa ilibe mankhwala (translated as: Let us avoid AIDS because it has no cure].

The above excerpt shows some conceptual integration of knowledge. The teacher integrated knowledge from Music, Dance and Life skills Education, when he asked the learners to come up with a song on any contemporary or cross-cutting issues and match the song with Manganje dance steps.

However, although learners recognised some connections between classroom knowledge and situations outside the classroom, but they did not explore the implications of these connections, so they remained abstract or hypothetical. In the above excerpt, when the teacher asked the learners about the significance of the song they sung, the learners mentioned issues like promotion of unity and cooperation among people. But the teacher did not actually engage the students deeply in any critical analysis of what they meant by unity and cooperation. The learners thus just mentioned the issues without making explanations of their thoughts.

\section{Problem-based curriculum}

Problem-based curriculum was weakly evident in the lessons, as learners were not engaged in solving real-world problems in the twelve classrooms. The lessons lost the rhythm of higher-order or critical thinking associated with high intellectual quality teaching and learning proposed by Productive Pedagogies. 
Summary of connectedness to the world beyond the classroom

The percentage of lessons and number of episodes indicating presence of Connectedness of lessons to the world beyond the classroom dimension in the 71 lessons are presented in Table 6 below.

Table 6: Percentage of lessons and number of episodes indicating presence of Connectedness of lessons to the world beyond the classroom

\begin{tabular}{|l|c|c|c|}
\hline \multicolumn{1}{|c|}{ Dimension } & Indicator 1 & Indicator 2 & Indicator 3 \\
\hline $\begin{array}{l}\text { Connectedness to the } \\
\text { world beyond the } \\
\text { classroom }\end{array}$ & $\begin{array}{c}\text { Connectedness } \\
\text { to the world }\end{array}$ & $\begin{array}{c}\text { Background } \\
\text { knowledge }\end{array}$ & $\begin{array}{c}\text { Knowledge } \\
\text { integration }\end{array}$ \\
\hline Percentage of lessions & $24 \%$ & $82 \%$ & $8 \%$ \\
\hline
\end{tabular}

\section{Supportive classroom environment}

This dimension was weakly evident in most of the observed Expressive Arts lessons. Only 27\% (18 out of 71) showed evidence of supportive classroom environment, although some parts of the lessons had some of its indicators. A detailed analysis of each indicator of Supportive classroom environment dimension of Productive Pedagogies as observed in the lessons is presented below.

\section{Student direction}

In all of the observed lessons, teachers determined students' activities during teaching and learning process such as listening, doing exercises in notebooks, group discussions and presentation of group discussions.

\section{Social support}

Seventy five percent (46 out of 71) of the observed lessons showed very limited social support. 
The excerpt below illustrates lack of social support in the observed lessons:

Teacher: Let us go to the ground to practice doing some of the mirroring activities which we discussed yesterday.

Teacher: Can you be in groups of 10. I do not want to see groups of boys only and girls only. Can that group demonstrate running on one leg from there to there? Can the rest of the groups do exactly what you have seen your friends doing, running on one leg for 20 metres and back? You two, you are very stupid. Why are you doing your own things? Why are you not running?

In this excerpt, the teacher did not provide social support to the learners. This is so because firstly, when the teacher noticed that the learners were engaging themselves in some off-task activities, the teacher disapproved their actions by reprimanding them, 'you too, you are very stupid. Why are you doing your own things? Why are you not running?' This may have left the concerned learners embarrassed and eventually dropping out of the lesson. Secondly, the teacher did not use or employ any other 'social support' techniques to teach the learners to listen attentively and concentrate on the teaching and learning task at hand, apart from the teacher rebuking the learners.

However, some teachers did try to give moral support and encouragement to the students. Of the lessons observed, only $35 \%$ (25 out of 71$)$ were characterised by social support. The main form of social support provided to the learners was praising them when they made a contribution in the lessons, showing them that their contributions were important. The ideas of learners were acknowledged by the teacher in such a way that the learners felt involved in class discussions. When a learner gave an incorrect answer, the teacher called upon other learners to come to the rescue of a colleague who had either given a wrong response or made no attempt to give an answer to a teacher's question.

\section{Engagement}

Students engagement in the teaching and learning process was hardly evident in the majority of the lessons. Only $27 \%$ (18 out of 71 ) of the lessons showed academic engagement of learners. In the remaining $73 \%$ (53 out of 71 ) of the lessons observed, much of the teaching and learning time was spent on classroom management, with a lot of time spent controlling students' behaviour. 
The excerpt below is an example of a situation with little academic engagement of learners in the teaching and learning process.

Teacher: O.K. today, we are going to continue our work. Have you got your materials for making the drums?

Learners (collectively):

Yes

[One group had 26 learners. One of the boys in the group complained, 'Mukundipwetekatu' (translated as: you are hurting me colleagues. Another boy agreed, 'Pachuluka anthu apa' (translated as: we are too many here). A third boy complained, 'Ndikuyesa ndikuchita kukankhidwa'(translated as: I am also being pushed). A fourth boy agreed, 'Inde pachuluka anthu apapa ntchito ikumativuta kugwira' (translated as: it is true, we are too many here, it is difficult for all of us to participate].

In this excerpt, there is little engagement of learners in the learning tasks of the lesson. This is so because firstly, the complaints of the learners, such as, 'you are hurting me colleagues', 'we are too many here', 'I am also being pushed', 'it is true, we are too many here, it is difficult for all of us to participate', show that there were too many learners in one group and as such it was difficult for each one of them to participate actively in the assigned work. Secondly, there was disruption of the class as learners were pushing and hurting each other leading to very little learning taking place in the groups. This was created by very large numbers of learners in the class.

\section{Explicit quality performance criteria}

Most of the teachers did not make the criteria for quality performance explicit. However, some teachers tried to gauge the quality of the learning of their learners by assessing their performance at the end of the lessons. For example, Teachers 2 and 10 assessed their learners' learning at least twice during their lessons. Only 6\% (4 lessons out of 71) showed some evidence of assessment for learning taking place within the teaching and learning process. However, the assessment activities were observed to be merely aimed at recall of facts. 
The excerpt below, illustrates some assessment, but only of factual recall.

Now can you take note books and quickly answer these questions.

[Teacher wrote the following questions on the chalkboard]

1 . What is mirroring?

2. Mention two activities which you can copy from friends?

[The teacher went around the classroom marking the learners. She did the marking for about five minutes].

Teacher: Most of you failed to answer the questions correctly.

The above excerpt shows that the teacher involved assessment of learners when she gave learners a class exercise, marked the exercise and gave them the expected responses to the questions. However, the episode shows that the assessment activity was based on simple recall of facts that were learned in that lesson and in the previous couple of lessons. This assessment activity, like the other three observed in the lessons, was different from that of the teacher's guide. The Standard 7 teacher's guide that the teacher used suggested the following assessment tasks for students:

1. What are mirroring activities?

2. Why are mirroring activities significant?

3. Describe some mirroring activities that you do at home and at school.

4. How do mirroring activities differ from other ordinary activities?

While Teacher 2's task only involved students to recall facts, the same task in the teacher's guide goes beyond simple recalling of facts. For example, the third and fourth questions of the task in the teacher's guide makes connections to students' lived experiences. Yet the teacher's assessment task did not make such connections.

\section{Summary of supportive classroom environment}

The majority of Expressive Arts lessons showed little engagement of learners in the teaching and learning process. The percentage of lessons and number of episodes indicating presence of Supportive Classroom Environment dimension in the 71 lessons are presented in Table 7 below: 
Table 7: Percentage of lessons and number of episodes indicating presence of Supportive Classroom Environment dimension in the 71 lessons

\begin{tabular}{|l|c|c|c|}
\hline \multicolumn{1}{|c|}{ Dimension } & Indicator 1 & Indicator 2 & Indicator 3 \\
\hline $\begin{array}{l}\text { Supportive classroom } \\
\text { environment }\end{array}$ & Engagement & Social support & $\begin{array}{c}\text { Judging student } \\
\text { performances }\end{array}$ \\
\hline Percentage of lessions & $27 \%$ & $35 \%$ & $6 \%$ \\
\hline
\end{tabular}

\section{Interpretation and conclusion}

Through a recursive categorisation of the research data, eight themes emerged as significant in the pedagogical practices of the Expressive Arts curriculum teachers in grades 7 and 8. These themes are: generally - lower intellectual quality lessons; the prevalence of localising pedagogic discourses; pedagogy for communalisation and subordination; pedagogy for syllabus completion; pedagogy for public examinations; weak integration of knowledge; limited connection of lessons to the outside world and over-dominance of instrumentalist knowledge. These themes are discussed below:

Lower intellectual quality lessons

This study found that the lessons lacked high intellectual quality in terms of in-depth coverage of the subject matter thus compromising possibilities for higher-order thinking and deep understanding on the part of the learners.

This result is consistent with other studies on the practice of Productive Pedagogies by teachers. For example, the study confirms what was found by Zohir and Razak (2010). Zohir and Razak, in his study of the classroom practice of productive pedagogies of Malaysian Secondary School Geography teachers, found that the level of intellectual quality in the geography classrooms were very low, as students were less involved with higher order thinking skills as most of the teachers did not encourage the students to think deeper and get actively involved during the teaching and learning process. The teachers in Zohir's study were observed to have been asking lower-level questions to the students. Students were observed only to receive information passively from their teachers most of the times. 
There are three major possible explanations for these findings. These are presented in the following sub-sections.

(a) Teaching for public examinations

Results of this study showed that teachers were teaching for and to high stakes examinations. The classes were to sit for public examinations in the year (2010) when this study was being conducted and the following year 2011. Mandatory examinations may therefore have influenced classroom

practices of teachers because the state uses grade eight examinations as the only tool for selecting students for secondary school education.

This study's finding support what other authors and researchers, for example Whitaker (1993), have argued that standardised testing forces teachers to teach in a way that will prepare learners for examinations, and this can affect the achievement of the broad goals and objectives of the curriculum.

(b) Assumption of deficit model

The teachers hold a 'deficit' belief about their learners. Teachers revealed that their pupils were slow learners and 'empty buckets', and as such, they need to 'give' the learners knowledge. This finding is consistent with the findings of Sarangapani's (2003) study of pedagogic practices of teachers in low-income, under-resourced schools in India. Sarangapani (2003) found that teachers in his study held a 'deficit' picture of their learners, and also employed expository teaching methods to give sufficient knowledge to their learners.

(c) Influence of English as language of instruction

Although teachers used English as a medium of instruction, they often switched to the vernacular whenever they noted that learners were not following. This increased the participation of learners. The slight improvement in participation of the learners in lesson activities when a teacher switched to vernacular indicates that the English language skills of the learners may be an obstacle affecting the participation of the learners in the lessons. Mkandawire (2004) found that students' participation reduced drastically whenever the class teacher switched from a local language to English. Kaphesi (2001) also found that the use of local language in grade five Mathematics class greatly increased students' participation in lesson 
activities. These significant research findings suggest that the use of English as a medium of class instruction in the Malawi primary school classrooms reduces students' active participation.

\section{Limited connection of lessons to the outside world}

This study found that teachers seldom made connections with the outside world. As many writers correctly observed, effective teaching is about making connections between classroom lessons and the outside world in which the students will be expected to display competent skills in active participatory life (see Barton and Levstik, 2004; Cogan, Grossman and Mei-hui-Liu, 2000). In fact, this kind of connection is what Cogan et al, and Giroux and McLaren (1999) contended that is important for providing students with the skills in critical thinking and development of positive attitudes about the real world. Similarly, Remy, Anderson and Snyder (1976) also observed that the greater the connections between the curriculum and the outside world, the higher the likelihood that the students can transfer the classroom experiences to the real life situations. However, the twelve teachers in this case study did not make links classroom activities and the world outside their classrooms. Yet the curriculum documents encouraged teachers to make such connections using resource persons, experts in various fields. Such lack of connection between the lessons and the outside world divorces education in Malawi from the knowledge society and the world we live in.

\section{Over-dominance of localised knowledge}

Data of this study showed that the majority of the Expressive Arts lessons observed were characterised by dominance of localised knowledge, particularly 'ethnic culture'. There were thus more episodes in which the lessons observed covered ethnic or local cultural beliefs and practices of the learners.

Interview with the teachers revealed that the teachers stressed cultural knowledge in their lessons because they did not want learners to forget about their cultural roots and identity. The legitimatising of 'ethnic' cultural practices can be considered to be good in its own right as it gives learners cultural identity as explained by the teachers. But authors like Young (1997), have criticised localising of knowledge for resulting in an education that is 
balkanising, and which divorces a country from the 'knowledge society' and the information age learners live in.

Weak integration of knowledge across subject disciplines

The Expressive Arts curriculum documents, such as the Teachers' Guide, stipulate integration of knowledge as one of the most important principles of teaching Expressive Arts as an integrated learning area. However, most of the content taught by the teachers in the majority of Expressive Arts was limited

to one subject discipline without linking the knowledge with content of other subjects comprising Expressive Arts.

This was followed up in post-lesson interviews. Teachers cited gaps in their own knowledge of the content of some of the subject disciplines which form Expressive Arts as the main reason for their failure to integrate content of different subjects in their lessons

This is consistent with what Naidoo (2006) found about challenges which teachers face in implementing an integrated curriculum. Naidoo noted that one of the challenges of implementing an integrated curriculum is that teachers may not have knowledge of all the disciplines integrated in the curriculum they are implementing. In her study on teachers' perceptions of the Integrated Learning Areas for the junior secondary school curriculum of the South African National Curriculum Statement (2002), Naidoo found that the majority of teachers in her study lacked confidence and were not able to teach integrated Learning Areas due to gaps in their own knowledge (of the various disciplines informing the Learning Areas).

This result is also consistent with the findings obtained by Zohir and Razak (2010). They found that most of the content taught by the geography teachers in the secondary schools in Malaysia was limited to the subject itself without linking the knowledge with other subjects' content.

Pedagogy for communalisation and subordination

The study found that generally students did not take and active role in any of the 12 classrooms. 
Students never asked their teachers questions whenever the teachers gave them the chance to do so. The students were always ready to answer questions from their teachers, but not asking them questions. Thus, although all the teachers knew the importance of involving all students in lesson activities regardless of their gender, their social-cultural backgrounds seemed to have ruled supreme in the decisions they made in the classrooms. Viewing from the lens of Productive Pedagogies theory, the socio-cultural experiences that both the teachers and students brought to class affirmed Malawian cultural epistemologies and ontologies that included subordination of learners, the young to the older. The implication of this affirmation of Malawian cultural epistemologies in the pedagogy of the teachers was the creation of a classroom environment that had very limited interactions between the teachers and the learners. This resulted in very limited or low intellectual quality of the Expressive Arts lessons observed.

This result also concurs with Tabulawa's (1998) study. Tabulawa's study, conducted in a senior secondary school in Botswana, sought to establish the practices of teachers in the implementation of learner-centred pedagogy advocated by the Ministry of Education in Botswana. As in Malawi, attempts to improve the quality of education in Botswana have included an emphasis on a learner-centered pedagogy. Tabulawa's study found that attempts at implementing the learner-centred pedagogy have produced disappointing results because much attention in preparing for the implementation of the learner-centred pedagogy focussed on provision of resources and training of teachers, but ignored the effect which the beliefs which teachers and learners bring to the classroom would have on the implementation of the learnercentred pedagogy. The findings of Tabulawa's study indicated that teachers'classroom practices were influenced by many factors other than technical ones: the teachers' assumptions about the nature of knowledge and the ways it ought to be transmitted, their perceptions of students, and the goal of schooling. It also emerged that the teachers' beliefs were incongruent with the basic tenets of the learner-centered pedagogy. Tabulawa concluded that the results of his study indicate that disregarding the effect of the beliefs which teachers and learners bring to the classroom on classroom practices when effecting change can lead to disappointing results.

These results have some implication on the productive pedagogies theory. One limitation of productive pedagogies theory is that it does not clearly stipulate the actual contexts of classroom interactive processes necessary for the development of skills in critical thinking and problem solving which it 
supports. From that perspective, this study suggests that creating an interactive classroom environment that treats students as rational beings is not a simple process as the theory assumes. There are factors that impinge on such processes, the critical one being the socio-cultural context in which a curriculum is being implemented.

This research used Lingard's et al. (2001) concept of Productive pedagogies to explore the pedagogic practices of Expressive Arts teachers in the primary schools in Malawi. The overall picture from the findings of this study is that classroom atmosphere in the twelve classrooms gave students limited opportunities for the acquisition of knowledge and development of skills, values and attitudes required for them to actively participate in the changing Malawian context and to be able to compete successfully in other contexts. It appears that dominant pedagogic practices in the Expressive Arts classroom serve to position learners in parochial orientations and issues. Therefore, there was an obvious disjuncture between the state's intended curriculum and the teachers' enacted curriculum. The results of this study show that Malawi would probably have done better by not taking the Outcomes Based Education considering the implementing problems it is facing which are associated with an OBE curriculum.

The implications of these findings for Malawi education have been raised. The most salient of these implications include the need for Malawi Institute of Education, the main change agent of primary school curriculum in the country, not only to consider revising the Expressive Arts curriculum but also to focus on the development of teachers in line with their needs for deeper content knowledge and learner-centred pedagogic strategies. 


\section{References}

Barton, K.C. and Levstik, L.S. 2004. Teaching history for the common good. London: Lawrence Erlbaum Associates.

Bernstein, B. 1971. On the classification and framing of educational knowledge.In Young, M. 2001. Knowledge and control: new directions for the sociology of education. London: Collier MacMillan, pp.441-461.

Boaler, J. 1997. When even the winners are losers: evaluating the experiences of 'top set' students. Journal of Curriculum Studies, 29(2): pp.165-182.

Cogan, J.J., Grossman, D. and Mei-hui-Liu. 2000. Citizenship democratic imagination in a global/local context. Social Education, 64(1): pp.48-53.

Croft, A. 2002. Singing under a tree: does oral culture help lower primary teachers be learner-centred? [Electronic version]. International Journal of Educational Development, 22: pp.321-337. Retrieved 1 March 2010 from www.elsevier.com/locate/ijedudev

Giroux, H.A. and McLaren, P.1999. Teacher education and the politics of engagement: the case of democratic schooling. Cambridge: Harvard Educational Press.

Glaser, B.G. and Strauss, A.L. 1976. The discovery of grounded theory: strategies for qualitative research. Chicago: Aldin Publishing Co.

Hayes, D., Ladwig, J., Lingard, B., Mills, M., Bahr, M., Chant, D., Warry, M., Ailwood, J., Capeness, R., Christe, P., Gore, J. and Luke, A. 2001. The Queensland school reform longitudinal study, Vols. 1 and 2. Brisbane: Educational Queensland.

Hugo, W., Bertram, C., Green, W. and Naidoo, D.2008. Bernstein, Bloom and the analysis of pedagogy in South African schools. Journal of Education, 43: pp.31-56.

Kaphesi, E. S. 2001. The use of language in mathematics teaching in Malawi. Unpublished PhD, University of Nottingham, Nottingham. 
Khomani, P. 2003. Implementing the Malawi Primary Curriculum and Assessment Reform. Zomba: Malawi Institute of Education.

Lingard, B., Hayes, Ladwig, J., Mills, M., Bahr, M., Chant, D., Warry, M., Ailwood, J., Capeness, R., Christe, P., Gore, J., Hayes, D. and Luke, A. 2001. The Queensland school reform longitudinal study. Vol.1 and 2. Brisbane: Educational Queensland.

McLaughlin, M.W. and Talbert, J.E. 1990. The contexts of teaching in secondary school: teachers' realities. New York: Teachers College Press.

Merriam, S. 2002. Qualitative research and case study applications in education. San Fransisco: Jossey-Bass.

Mhango, A.C.M. 2010. An exploration of the teaching of social studies in primary schools in Malawi. Unpublished PhD Thesis, Virginia Polytechnic Institute and State University, Blacksburg.

Moore, R., Muller, J. 2001. The discourse of 'voice'and the problem of knowledge and identity in the sociology of education. British Journal of Sociology of Education, 20: pp.189-206.

Mkandawire, M.T. 2004. Attitudes and views on local languages as media of instruction in Malawi. Unpublished Masters, Virginia Polytechnic Institute and State University, Blacksburg.

Naidoo, D. 2006. Curriculum, context and identity - an investigation of the curriculum practices of grade 9 teachers in three contrasting social-economic school contexts. Unpublished PhDThesis, University of KwaZulu-Natal, Pietermaritzburg.

Oakes, J., Gamoran, A. and Page, R. 1992. Curriculum differentiation: opportunities, outcomes, and meanings. In Jackson, P.W. (Ed.) Handbook of Research on Curriculum. New York: Macmillan.

Remy, R.C., Anderson, L.F. and Snyder, R.1976. Citizenship education in elementary schools. Theory into Practice, 15(1): pp.31-36.

Sarapangani, A. 2003. Ethnography of learning in a northern Indian village. International Journal of Educational Development, 30(2010): pp.297-304. 
Tabulawa, R. 1998. Teachers' perceptions on classroom practice in Botswana. Implications for pedagogical change. International Journal of Education, 11(2): pp.20-30.

Whitaker, T. 1993. Curriculum theory, design and assessment. Vancouver: Grant Mc Ewan College Press.

Young, M. 1997. The curriculum of the future: from the new sociology of education to a critical theory of learning. London: Routledge.

Zohir, M., Razak, N. 2010. Exploring the clasroom practice of productive pedagogies of the Malaysian secondary geography teacher. Journal of Review of International Geographical Education, Vol.2, No.2, Summer, 2012. 


\section{Appendix 1}

Sample analysis of an Expressive Arts lesson using productive pedagogies framework

\begin{tabular}{|c|c|}
\hline $\begin{array}{c}\text { Transcription of lesson } 2 \text { of Expressive Arts taught } \\
\text { by Teacher 2, in Standard } 7 \text { at school 'A,' a rural } \\
\text { school on } 08 / 01 / 2010\end{array}$ & Analysis \\
\hline $\begin{array}{l}\text { 11:50 a.m.: Teacher: Good morning class Learners: Good } \\
\text { morning madam }\end{array}$ & \\
\hline Teacher: How are you? & \\
\hline Learners: We are very well madam and how are you? & \\
\hline Teacher: I am very well. Sit down & \\
\hline Learners: Thank you madam & \\
\hline $\begin{array}{l}\text { Teacher: Yesterday, we learned about mirroring. We said } \\
\text { that mirroring are activities which somebody } \\
\text { can mirror from his friends. Can you tell me } \\
\text { what we said mirroring is }\end{array}$ & Social skills-instrumental \\
\hline $\begin{array}{l}\text { Learner: Mirroring is an activity in which somebody } \\
\text { imitates a friend. }\end{array}$ & \\
\hline $\begin{array}{l}\text { Teacher: Yes? Learner: Mirroring is an activity which } \\
\text { you copy from a friend }\end{array}$ & \\
\hline Teacher: Yes Learner: Mirroring is an action of copying. & \\
\hline $\begin{array}{l}\text { Teacher: Yes, what else? Learner: Mirroring is activity } \\
\text { which someone can copy. }\end{array}$ & \\
\hline $\begin{array}{l}\text { 11: 55: Teacher: Mirroring is an art of copying an action, } \\
\text { words or expressions. Yesterday, we looked at } \\
\text { some of the activities which you copy from } \\
\text { friends. Can you mention the activities which } \\
\text { you copy from friends? }\end{array}$ & Social skills-instrumental \\
\hline Learner: Running & \\
\hline Teacher: Yes, another one? Learner: jumping & \\
\hline
\end{tabular}


Teacher: What else?

Learner: Dancing

Teacher: Yes, you?

Learner: Singing

Teacher: The activities you have mentioned are some of the activities which we said yesterday that you can copy from each other.

12:00: Teacher: Let us go to the ground to practice doing some of the mirroring activities which we discussed yesterday.

12:02: Teacher: Can you be in groups of 10. I do not want to see groups of boys only and girls only. Can that group demonstrate running on one leg from there to there. Can the rest of the groups do exactly what you have seen your friends doing, running on one leg for 20 metres and back.

You two, you are very stupid. Why are you doing your own things? Why are you not running?

12:10 Teacher: You, three of you come here. You are going to show to the rest what we are going to do next. Two of you are going to hold hands and someone is going to sit on your joined hands. You are then going to run from here to there. Can you do that? Can you be in threes and practice lifting each other on joined hands and run..

12:15: Teacher: Now we will do another activity which combines a song and dancing. The song is called "nzamazama". Do you all know this song?

Learners: Yes Teacher: Can you make a circle and move around the circle while you sing the song "nzama-zama."

12:20: Teacher: O.k., thanks, can you go back to class.
Intellectual quality - low order thinking-knowledge is represented as facts and there is no sustained conversation between the teacher and the learners

Engagement with differenceinclusivity

Unsupportive classroom environment.

Knowledge integration 


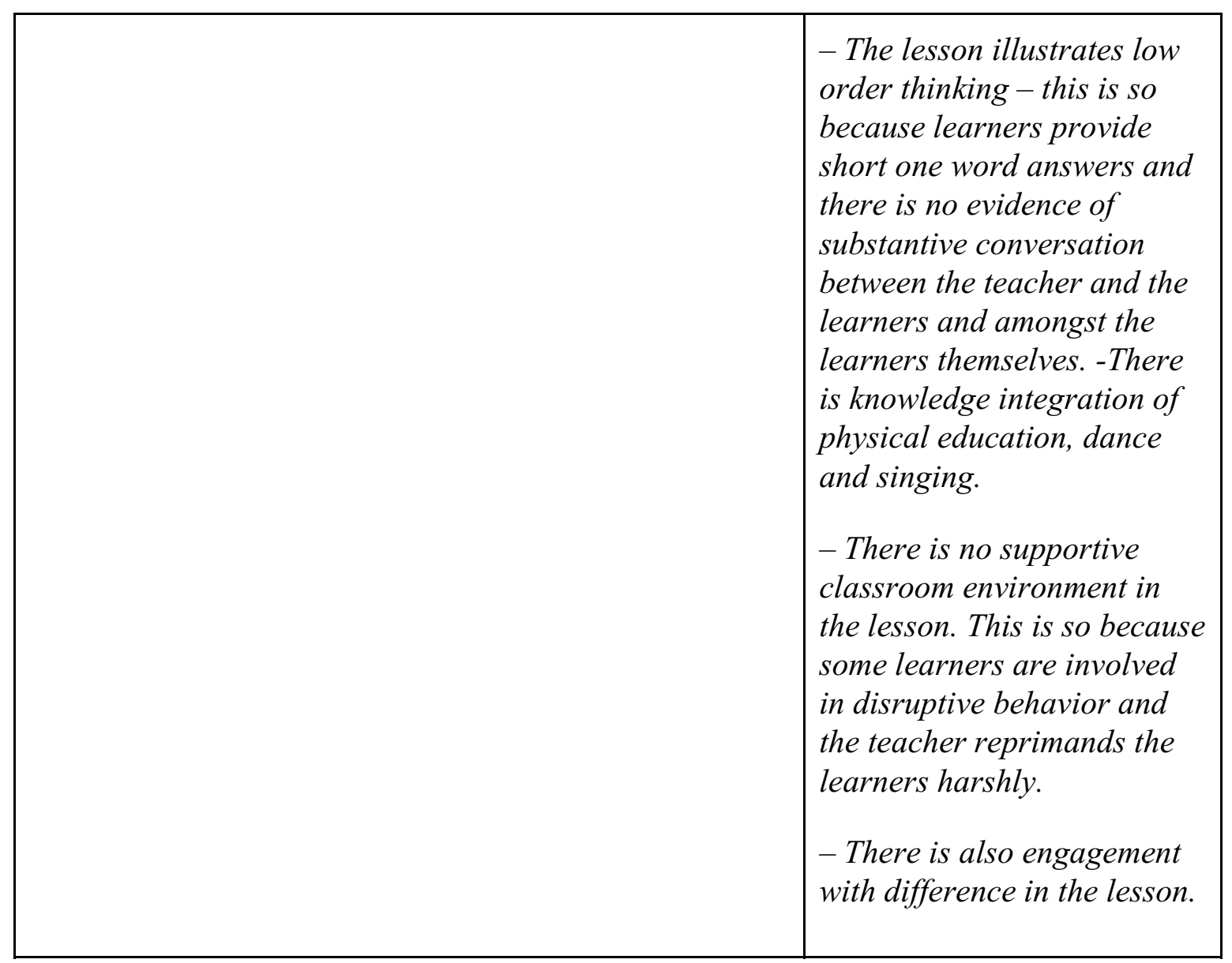

Devika Naidoo

Grames Chirwa

University of Johannesburg

devikan@uj.ac.za

grameschirwa@yahoo.co.uk 